\title{
Classification of Theories about Rock Pressure
}

\author{
Oleh Khomenko ${ }^{1, a^{*}}$, Maksym Kononenko ${ }^{1, b}$, \\ Janchiv Bilegsaikhan ${ }^{2, c}$ \\ ${ }^{1}$ Underground Mining Department, National Mining University, 19 Yavornytskoho Ave., \\ Dnipro, 49005, Ukraine \\ ${ }^{2}$ Newcom Mining Service Limited Liability Company, Ulaanbaatar, Mongolia

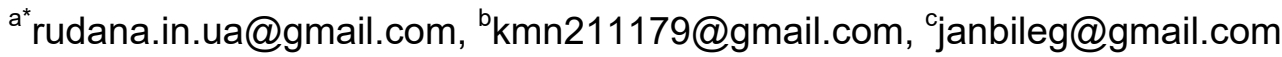

\begin{abstract}
Keywords: Rock Hardness, Rock Pressure, Classification of Theories, Energy of Massif, Capsule of Mine Working.
\end{abstract}

\begin{abstract}
The first classificationsw of physical properties of rocks and hypotheses of rock pressure in the world practice are analysed. The analysis of internationally widely known theories about rock pressure and physical processes around mine workings is executed. Classification of theories about rock pressure on classification feature "condition of investigated massif" is constructed. The energy theory that describing capsulation by the massif of underground mine working is offered.
\end{abstract}

\section{Introduction}

V. Trompeter has revealed zonal structuring of the massif around underground mine workings in 1899 and further only separate processes of this phenomenon were investigated. Since the end of the 19th century, research have been conductedt mainly in the direction of of the so-called phenomenon of zone disintegration of rocks around underground mine workings description. The phenomenon of zonal disintegration of rocks has been opened for the first time at the gold mine of South Africa (1972) and further in USSR (1978), Russia (1992), Ukraine (2002, 2006), etc. Researchers from Ukraine, Russia, Kazakhstan, Poland, France, USA, Canada, Japan, Republic of South Africa and other countries all over the world were studied various aspects of phenomenon [1].

The paradoxicality of the phenomenon of zonal disintegration of rocks around underground mine workings, according to I. Kaydo's opinion is that it contradicts with ideas of classical mechanics of rocks of a massif's condition. According to them, the movement of the front of ultraboundary deformation from a mine working contour deeper into of the massif with formation of zones of elastic, elastic-plastic and plastic states is impossible. It initiated emergence of the hypotheses that rejecting physical reality of this phenomenon during 20 years from the moment of opening. In the 80th of previous century, hypotheses and mathematical models based on mechanics of flowing, continuous and discrete environments were actively offered. Abstraction from true structure of substance and lack of accounting of the proceeding physical processes was a basic lack of research of this period. The models that considering structure of the massif by mesomechanics methods were actively developed for elimination of these shortcomings since 90th years. Also the hypotheses that based on regularities of periodic rock pressure, autowave processes, substance clustering on macroand nanolevels, a liquid tension, formation of fractals, self-coordinated field, gradation of "dark energy" in "dark matter", etc. Unsuccessful attempts of the description of physics of this phenomenon with application of mechanics methods and new methods of mining science have even more increased necessity of development of the synergetic methods of research that answering to modern ideas of interaction of matter and energy in the nature [2].

Nowadays, scientific and practical interest is represented by the analysis and drawing up the classification of theories about rock pressure without switching of attention to research of this phenomenon of zonal disintegration. The received results will allow defining the main advantages and shortcomings of fundamental theories that have been analysed yet. These results are necessary for comparison of conditions of zonal desintegration manifestation with geodynamic data that were obtained in mines of Ukraine. It is obvious that this phenomenon has no connection with the strength of 
rocks on compression and, respectively, with dynamic factor [3]. Confirmation about formation of ring zones around workings is a protective reaction of the massif to formation of cavity, and all geodynamic processes are just destruction of the zonal-and-energy system that protecting mine working. Confirmation that the system of protective zones around underground mine working would be expedient to call the safety capsule, and a phenomenon as zonal capsulation of underground mine working. Non-disclosure of essence of this phenomenon was recognized as the research community as one of the most difficult scientific problems, not giving in to the description based on modern representations of physics [4] until recently. Long time was considered that it is one of the first physical phenomena for which description are required philosophical interpretation and developments of the energy theory with attraction of the device of synergetrics, quantum mechanics, checking of convergence of modelling results on mega-, macro- and microstructural levels of material bodies and the physical fields surrounding them. Attention will be paid to all these questions in general and final material of the article [5].

\section{Theories about Rock Pressure}

The mining science was allocated in independent branch of knowledge in the middle of the 16th century, having begun with examination of rocks physical properties and their classification by various technological signs, extraction and explosibility became first of them. The first attempts to generalize and record the accumulated experience were undertaken in 1556 by G. Agricola. In 1788, A. Verner has offered a new classification scale of rocks hardness that has widely extended in mining practice. In 1878, A.Verner's classification has been developed and improved by the Austrian scientist F. Rzhikhoy by means of increasing in quantity of rocks classes up to seven, on the base of which the amount of the energy demanded for 1 cubic meter of ore extraction has been underlied.

In 1896, K. Dolzhalek has grouped rocks into 6 classes labour amount that spent for 1 cubic meter of ore mining. Based on production experience, P. Shalon has received coefficients of relative rock hardness on explosibility. M. Protod'yakonov firstly offered application of rock hardness coefficient for calculation of loadings on support in 1886. Further, articles of Tetmayer and H. Koch concerning to rock hardness and ratios between ultimate stress limit of rocks at compression, displacement and flexure, etc. In 1910, M. Protod'yakonov has improved F. Rzhikhi's classification and has substantiated numerical value of hardness coefficient with taking into account ultimate stress limit of rock at compression.

The dome formation phenomenon in a roof of mine workings became a subject of serious scientific examination in the second half of the 19th century. In addition, attempts of hypotheses substantiation of stress state of the undisturbed massif of rocks and its change with a depth were executed. In 1867, P. Schultz has established qualitative dependence of rock hardness from dome shape. In addition, there was a steady opinion among scientists, that pressure doesn't depend on depth at which mine working is drived. This opinion occurred until depth of mining operations on mines of Upper Silesia hasn't reached $300 \mathrm{~m}$, and on mines of Zwickau to $400 \mathrm{~m}$ from the land surface, where costs of bolting and mine workings maintenance that were destroyed by rock pressure have increased almost twice.

On Pshibramsky silver-lead mines of Silesia and Dombrov with a depth of mining over $300 \mathrm{~m}$, cases of "rock outburst» have appeared. More often and worst, pieces of rocks with a big force and a sharp crash are came off from the massif in sides of mine workings, rarely in the bottom and even more rarely in a roof. With a depth of $300 \mathrm{~m}$, the domes of stable equilibrium in a roof were formed right after mine working drivage. High abutment pressure on the plane of stoping faces facilitated coal mining which due to effect of extraction almost collapsed by itself with insignificant external help. About existence in rock massif of considerable stresses that are capable to destroy any support, G. Mantsel has said very accurately and unambiguously in 1894.

The first scientific theory about forces that operating in undisturbed rock massif has proved by the Swiss geotechtonics scientist A. Heim [6] in 1878. Pressure of rocks according to A. Heim is a weight of rock strata. Pressure in undisturbed massifs is acting in all directions hydrostatically and 
on absolute value: $\sigma_{z}=\sigma_{x}=\sigma_{y}=\gamma H$ at $\tau_{\max }=0$, where $\sigma_{z}, \sigma_{x}, \sigma_{y}$ - respectively, vertical and horizontal components of hydrostatic pressure; $\gamma$ - the average volume mass of rock; $H$ - depth of mining operations. A. Heim's theory about stresses in undisturbed rock massif finds reflection in works of S. Avershin, J. Talobr, L. Müller, etc.

In 1899, the German surveyor engineer W. Trompeter has suggested about existence of three zones with various level stress state of rcoks around mine working [7]. According to W. Trompeter, directly to mine working is adjoined zone of massif that unloaded from the natural stresses (zone of lowered pressure) within of which, rock collapse is happening. Stresses in this zone are much lower than presented in massif before mine working drivage. The second zone that enveloping the first one is a zone of increased pressure. It perceives on itself pressure of all overlying rock strata and protects mine working. The third zone is a zone of elastic condition of rocks that on the level of stress state corresponds to the undisturbed massif of rocks. The qualitative explanation by W. Trompeter about regularities of formation of stress state of rocks around mine working was the first serious contribution to the subsequent development of the rock pressure theory. The name of $\mathrm{W}$. Trompeter has been appropriated to the zone of lowered pressure that covered by the dome formation process.

At the end of the 19th century, the set of various theories has appeared, in 1867, one of the first P. Schulz's theory considering rcok layer in a roof of mine working or stoping space as the bent beam has been published [8]. Schultz finds the admissible length of exposure of a layer in a roof of stoping space: $2 a=\left(2 h K_{6} \gamma^{-1}\right)^{0.5}$. However, P. Schulz solves a problem only for a separate elastic layer, in other words immediate roof of a coal seam, though in nature there is a significant amount of the layers of rocks lying one over another and not connected among themselves, such as false roof, adjacent seams, etc.

The interesting analytical solution of the task about the rocks collapse in a roof of horizontal mine working has been proposed by Ritter [9] in 1879. The author recognized well-known fact that dome-shaped volume of rocks seeks to come off and fall in roof rocks. The task came down to definition of equation of a curve of a separation and pressure upon the support. Case bay of steady exposure of a flat roof according to W. Ritter is equal to $2 a=K \sqrt{48} \approx 7 K$. As we see, W. Ritter has analytically solved a classical problem about dome formation over mine working. The main shortcoming of $\mathrm{W}$. Ritter's decision consists in coefficient $\mathrm{K}$, that dimensional in meters. Its physical sense remained the obscure even the author of the theory.

In 1882, F. Engesser has executed laboratory research of dome formation in granular materials [10]. He considered that in such materials unloading pressure dome is independently formed. However, as in fact this dome consists of the separate particles that don't connected one with another, moving of particles is possible down if only not to prevent it by special vertical forces. Having designated the angle of friction of granular material $\varphi$ and density $\gamma$, F. Engesser, proceeding from the theory of Coulomb, determines passive horizontal pressure $\tau$, that caused by vertical pressure $\tau=\sigma \operatorname{tg}^{2} \frac{90^{\circ}+\phi}{2}$ or $\sigma=\tau \operatorname{tg}^{2} \frac{90^{\circ}-\phi}{2}$. The remarkable thing is that F. Engesser has established dome formation in granular weight with a certain height of material for the first time. If the thickness of granular material is insufficient, so the layer height in relation to width of mine working is less than $3-4$, all column of rock is pressing on support. At the bigger relation of height of rock mass to mine working's width, the unloading dome is formed in its roof.

In 1885, N. Fayol's [11] work which isn't containing any mathematical theory, but comprising the description of numerous laboratory research and data of direct observations in the mines opening a qualitative picture of the occurring phenomena has been published. The author investigates bending of rock layers of a roof in stoping space and determines regalarity of this process. He has shown difference in stratification and a deflection of rock layers which possess on various removal from a roof for the first time. If clay at compression up to $100 \mathrm{MPa}$ continuously decreases in volume, then shale already with a pressure of $10 \mathrm{MPa}$ increases in volume by $28 \%$, sandstone by $36 \%$, and coal by $30 \%$. Further growth of pressure is followed by reduction of rocks 
volume. N. Fayol has been investigated process of containing rocks collapse due to horizontal, inclined and steep-deeping deposits mining on a large number of models.

In 1912, O. Kommerell [12] has attempted to determine dome height by the deflection of a layered roof of mine working for the first time. The formation of stable equilibrium dome over mine working in which the rock is cracks and breaks into pieces is the basis of his theory. For convenience of calculations, $\mathrm{O}$. Kommerell has been accepted the elliptic dome of the same width and height instead of parabolic ones. The measured roof $l$ deflection in the middle of mine working has to be equal to linear $b$ dome height increment, so $l=c b$ or $b=l c^{-1}$. From here it is the ellipsoid equation $a^{-2} x^{2}+c^{2} l^{-2} y^{2}=1$. The area of a half of an ellipse representing on $\mathrm{O}$. Kommerell as the square of the dome is equal to $S=0.5 \pi a b$ and the weight is equal to pressure upon a support $P=0.5 \pi \gamma a b$. O. Kommerel's theory is simple, however it is very complicated to use it, as the mine working have to be already drived and measured roof sagging that doesn't allow to apply it during design of a drivage and bolting of mine workings.

In 1908 - 1910, A. Leon has given the strict mathematical solution of a task on stresses distribution around mine working of round section that drived in elastic rock [13]. A. Leon solves the task on the basis of the general equations of balance. The single thickness of a point $\mathrm{M}$ is taken in a layer radial $\sigma_{r}$, tangential $\sigma_{t}$ and tangents $\tau$ stresses and described by equations $\sigma_{r}=p\left(1-\sin ^{2} \alpha\right), \sigma_{t}=p \sin ^{2} \alpha, \tau=p \sin \alpha \cos \alpha$. A. Leon's theory was generally recognized and was widely used for calculation of stresses around mine workings of a round shape. Existence of an opening causes increasing in stresses near its contour and their subsequent reduction in process of removal from mine working. Rock mass pressure $\gamma H$ is accepted as the acting vertical stresses in calculations. From A. Leon's theory, it is follows that formation of mine working causes change of stresses in the massif on its entire perimeter, both in sides, botttom and roof.

In 1915, Levinson-Lesing and A. Zaytsev's research on optical-and-polarizing materials of nature of distribution of stresses around mine workings of different shapes were contributed to the further development of the theory of rock pressure [14]. All shapes of openings cause, as well as in A. Leon's theories, the considerable diagonal, tangential stresses. The largest stresses occur on sides of openings, in other words in the plane, perpendicular to the direction of action of bigger normal stress, the smallest are in direction of the acting effort. Experiences demonstrate that rather small stresses arise in sides of mine workings of oval, elliptic and horseshoe-shaped forms which long axis is focused in the direction of the acting effort. Significantly big stresses occur in mine working sides in that case when the form of an opening is extended in the cross direction to the acting effort, in other words there is no pressure upon a support at the same time.

From 1908 to 1912, M. Protod'yakonov has created and checked by practical consideration the theory of rock pressure upon the mine support [15]. According to his opinion, support is under the pressure only within the dome. Proceeding from the area of a parabola and volume mass of rocks, M.M. Protod'yakonov removes a formula for calculation of pressure upon the mine working's support $P=\frac{4}{3} \gamma a^{2} f^{-1}$. These works play a significant role in calculations of support for mines up to $150-200 \mathrm{~m}$ in depth. At depths of $500-700 \mathrm{~m}$, the difference in the values of height of the dome is calculated by his formulas and which are directly measured in mines becomes very essential. Besides, the offered formulas are suitable only for single mine workings.

Considerable achievement in development of the theory of rock pressure was development of the new hypothesis of stress of the undisturbed massif of rocks in 1925 by A. Dinnik [16] in which the condition of balance of single volume of rock (cube) with the edges that located vertically and horizontally is considered. For calculation of the compression stresses $\sigma_{1}$ and $\sigma_{2}$, change of length of an edge of an elementary cube in the direction of an axis $O X$ was determined. A. Dinnik's hypothesis differs from A. Heim's one in the fact that horizontal stress doenn't equally to vertical and is only some part of the last. A. Dinnik's theory can use only for determination of stress in the massif of rocks before mine working drivage in itm. Emergence of the theory of A. Dinnik has been 
caused by urgent practical necessity of the decision with sufficient extent of approach of difficult practical tasks of mining.

\section{Theories about Physical Processes around Mine Workings}

From 1925 to 1938 , data about rock pressure manifestations during underground mining had been accumulated. The factors influencing on rock pressure manifestation in longwalls of coal mines have been divided into two groups: natural and artificial. Based on experienced examination of specified factors influence, practical recommendations about management of rock pressure were developed [17]. The theory of dome formation over stoping space of coal layer has gained further development in V. Slesarev's work [18]. His doctrine about equivalent case bays contains wrong statements that for any mine working of limited contour it is possible to find equivalent working of infinitely big length which roof will be in the same conditions of balance, as a roof of given chamber in the plan. Stability of roof rocks is determined not by the length, but mine working width, as W. Ritter, M. Protod'yakonov, and others have already proved it.

In 1937, Dzh. Spelding based on direct measurements of deformations in mine workings of the "Champion Rif" mine (India) has described effect of unloading of initial stresses that fades away with removal deep into the massif [19]. Loading that directly adjacent to mine working is transferred to more remote sites of the massif where stresses are concentrated. The total effect of reduction of primary stresses is that mine working appears surrounded cover of increased stresses. Between the zone of stresses concentration and contour of mine working, the area of lowered stresses which size decreases up to zero on the surface of exposure is created. Therefore, Dzh. Spelding has given qualitatively new picture of process of unloading of initial stresses around mine working.

R. Fenner in 1938 and A. Labass have laid the foundation for analytical research of nature of stresses distribution around mine workings in 1946 - 1947. They have created well-proportional mathematical theory that reflecting processes of rocks deformation near the surfaces of exposure [20]. R. Fenner's theory proves and explains existence around a cavity in elastic medium of a zone, free from stresses, and zone of lowered stresses around a cavity in the plastic environment. A. Labass has developed R. Fenner's ideas and also proved that mine working is surrounded with three zones: lowered pressure (zone of Trompeter); increased pressure; natural stresses that taking place before mine working drivage [21]. According to R. Fenner and A. Labass's research, it is follows that acting in the massif stresses were determined by them on sizes of deformations of stretching and displacement. In addition, supporters of "hypotheses of deformations" were famous theorists K. Ruppeneyt and V. Liberman [22, 23].

From 1944 to 1961, the set of works about rock bursts during tunnels construction, extraction of ore on zinc-lead mines of Blayberg, and others, S. Avershin [24], R. Kvapil [25], R. Morrison [26] has been published, and developed theoretical bases of rock burts during underground mining of deposits. In 1955, S. Avershin has noted that phenomena connected with stress of rocks remain poorly examined. Among these phenomena, rock bursts belong to the least examined, despite semicentennial history of their examination. R. Kvapil considers that rock burst is the release of rock from stress that is followed by instant transition of the accumulated potential energy to work beyond a limit of elasticity and durability of rock. S. Avershin recognized that elastic forces, deforming a body, making work that is equal to the sum of works of these forces on the deformations caused by them. Rock bursts arise in the areas of overstrain of the massif that getting to zones of abutment pressure. The largest stresses before mine working drivage has been directed vertically, and during its appearance in the massif has deviated on vertical. Along the average horizontal line of a stress deviation towards mine workingt are replaced by its alignment to the vertical direction, and then trajectories deviating to mine working and again leveled to a vertical at the distance equal to mine working's height.

R. Kvapil [27] offered qualitatively new explanation of regularities of physical processes. He recognizes situation that all changes which are undergone by crust as a result of mining operations conducting submit to natural laws. Certain conditions of distribution of potential energy that are 
characterized by the law of optimum balance are correspond to condition of the site of crust. R. Kvapil has proved by theoretical research that near mine working there is a zone of an elliptic shape that is characterized by the weakened amount of potential energy and zone of the lowered stresses. In process of removal from a mine working's contour, the level of potential energy increases in the massif and at a certain distance reaches the maximum. Further, deep into the massif, the level of potential energy decreases to initial, thereby explaining essence of rock pressure which reason is connected with energy, and its manifestation with forces.

In 1967, N. Hast has performed for the first time very exact measurements of elastic deformations in rock massifs of Scandinavia by the method of unloading [28]. The author has revealed that in rock massif, the horizontal compression stresses in several times exceeding the geostatic stress. It was confirmed by measurements of elastic deformations in mining regions of the world: Mountain Shoriya, Donbas, Sayan Mountains, Kazakhstan, Kola Peninsula, Urals, Altai, Kursk Magnetic Anomaly and also Norway, Spitsbergen, Ireland, Canada, Africa, Southeast Australia, Iceland, Alps, Portugal, Malaysia, USA [29, 30].

From 1974 to 2010, A.Savost'yanov's works concerning theoretical bases of management of rock massif condition [31] had been published in scientific-and-technical literature. Having made the analysis of the main mechanical properties of sedimentary rocks, and having made physical modeling on equivalent and optical-polarizing materials, the author has received regularities of displacement of the layered massif that have been confirmed by production data. For modeling of displacement of layered rocks, the laws of resistance of materials that were considered in the form of the beams strips lying on the pliable basis were used. Features of calculations of stress-strain state condition of a rock layer during bending was that change of normal stresses both in a zone of a limit state, and from a maximum up to stresses of the undisturbed massif practically, submitted to the linear law. As a result of the analysis of influence of natural, technology and temporary factors on a condition of the massif of rocks it is established that diagram of loadings which are formed around stoping and preparatory mine workings consist of several zones of abutment pressure.

V. Lavrinenko, based on fundamental laws of physics, during 1975 - 1999 has developed the thermodynamic theory that disclosing regularities of formation of stress state, physical properties and temperature of rocks of the undisturbed and broken massif in the thermobaric conditions of bowels of the earth that changing with a depth. Stress state of the undisturbed massif is formed under the influence of the gravitational pressure that caused by the weight of the leaning rock mass and the spontaneous processes that connected with redistribution of potential energy of elastic deformation. At the considered depth $H$ from the land surface the initial single volume of rock (thermodynamic system), being exposed to compression by gravitational pressure $\sigma_{z}=\gamma H$, and changes parameters of the state [32].

Due to the substance consolidation, the volume occupied by system at a depth $H$ is equal to $v_{i}=K_{y}^{-1}$, and density $-\gamma_{i}=\gamma_{o} K_{y}$. At the same time $v_{i}<v_{o}$, but $\gamma_{i}>\gamma_{o}$. Therefore, vertical a component of gravitational pressure of rocks at a depth of $M$ it will be equal to $\sigma_{z}=K_{y}^{\prime} \gamma_{o} H$; here $K_{y}^{\prime}$ - average value of coefficient of consolidation of rock in the considered interval of depths $H=0$ and $H=H_{i}$. Poisson's coefficient at volume stress state $\mu=0.5-\left(K_{y}-1\right)\left[6 K_{y}\left(1-K_{y}^{-0.33}\right)\right]^{-1}$ with taking into account consolidation of rock. Horizontal components (jet) of gravitational pressure in this case on an absolute value are equal to $\sigma_{x}=\sigma_{y}=\mu(1-\mu)^{-1} \sigma_{z}$. At $\mu<0.5, \sigma_{z}>\sigma_{x}$, so the external acting stresses in various parts of thermodynamic system isn't identical. Compression of system the single volume of rock, forces of gravitation is followed by volume deformation $\Delta v=\left(K_{y}-1\right) K_{y}^{-1}$. Thus, rocks that lying at different depths represent deformed (in comparison with an initial state) solid bodies. Elastic potential stresses $\Delta \sigma_{x(y)}=\Delta \sigma_{y(y)}$, acting in the horizontal plane, on an absolute value it is more than $\Delta \sigma_{z(y)}[33]$. 
Applied aspects of the theory allow determining absolute value of radial and tangential actual stress as approaching to mine working's contour from border of a zone of unloading stresses. In view of that, the theory explains the reasons of deformation of the set of balance in a roof, bottom heaving in the bottom and collapses in sidewalls, the mechanism of emergence of actual stresses fields outside the massif of a zone of the unloading adjoining to mine working remained out of the field of a research. The perspective which is expressed in application of rock pressure energy in the course of preparation, cutting, stoping mining of blocks at mutual influence of more complex network of mine workings outside a zone of unloading and imposing of zones of stresses concentration is being not examined and doesn't allow to operate systemically by technologies of ore extraction [34].

The power theory of $\mathrm{O}$. Khomenko has substantiated that with changing of gradients of stress, density, temperatures, gaz-and water saturations, and the broken massif forms safety capsule which near-the-contour zone is epicenter of mine working of autowave sinusoidal damped oscillations of gradients around mine working. These processes lead to formation of ring zones of balance and an imbalance of energy which ratio of the sizes is described by sedate dependences. Modeling of preparatory and clearing mine workings drivage in rocks with the durability $40-200 \mathrm{MPa}$ and depth of mining up to $5000 \mathrm{~m}$ has allowed to reveal power functions that define a ratio of the sizes of power zones. This ratio is a constant $\left(a_{n+1}-a_{n}=\right.$ const $)$ which the shape and amount of development, depth of laying and property of the containing massif don't influence on it [35].

Increasing in quantity of power zones in the safety capsule of mine working at decreasing in rock strength and increasing in depth of mining that is described by the system of polynomial dependences of the fourth order is happened. A limit of development of wave processes around mine working is establishment of power balance in the safety capsule and equating of its durability with the undisturbed massif. It is revealed that energy of the capsule that formed around mine working can be used according to parabolic-and-hyperbolic dependence that values correspond to the reasonable principles: counteraction, equilibration, assistance, elimination and transferring of the concentrated energy of the massif. The effective choice and application of developed geopower technologies is provided with their systematization by the principle of energy management of the safety capsule (counteraction, equilibration, assistance, elimination and transferring), amount of the used energy in technologies $(0-86 \%)$. Also the type of mining operations (preparatory, stoping) and depth of mining operations (100-3000 m) at the mining enterprises (PJSC Kryvorizsky IOP, PJSC “Zaporizskyi IOP”, SE "Vostochnyi IOP” and PJSC Marganetskyi IOP).

The offered ways of preparatory operations improvement included development of temporary bolting of preparatory workings face that is realised from $100 \%$ by counteraction of capsule energy. Application up to $10 \%$ of massif's energy according to the principle of elimination is possible due to laying of routes of workings on ellipsoidal borders of near-the-contour power zones around stoping chambers [36]. It is possible to achieve application up to $35 \%$ of massif's energy according to the principle of elimination during laying of sub-level drilling drifts behind area of intensive destruction of rocks. Attachment of ellipsoidal contours of the plane of a face and section of preparatory workings allows to increase stability of exposures, and additional application of selfregulating bolting; to use up to $86 \%$ of the energy that generated in the safety capsule of mine working [37]. Developed technological decisions on stoping operations improvement of included definition of a steady form of elaboration of cutting [38]. The steadiest form of structural elements of blocks on the deep horizons of ore mines is reached by attachment to contours of ellipsoidal forms by the principle of equilibration that is implemented without additional expenses of energy. The rational direction of operational wells drilling in near-the-contour zone to the stoping chamber, contributes to primary ore crushing due to increasing in distance between the ends of wells that allowing to use up to $10 \%$ of the massif's energy [39].

The executed systematization of technology solutions on management of the worked-out area of mines aduring mining of Kryvbas deposits allows to consider the technogenic factors that influencing on energy condition of the massif and showing the ways of its minimization. Besides, the main technology solutions allowing to lower or alter technogenic loading and more accurate accounting of technogenesis in the massif on the basis of which the possibility of production of the 
accompanying jaspilites in the conditions of Kryvbas is possible. The way of mining of the accompanying granites is developed for conditions of attenuation of mining operations in withdrawal of mine deposits of Nikopol-and-Marganetsky basin. Technologies of extraction of ornamental stone materials in the conditions of technogenesis of subsoil are also developed. It is established that the amount of the used energy of the massif leads to growth of economic efficiency of preparatory operations on sedate dependence, and stoping on linear one. The received results have allowed proving new technologies of opening, preparation and mining of ore fields in Ukraine that allow to use $86 \%$ of energy of rock pressure with economy of resources up to $37 \%$.

\section{Conclusions}

1. The analysis of scientific results and the main shortcomings of the pro-classified theories has shown that V. Trompeter has revealed zonal state of the massif in 1899 and further only separate processes of this phenomenon were described. It has led to the fact that many theories won't be coordinated among themselves, and some of them contradict laws of physics. Any of theories, except the thermodynamic of V. Lavrinenko and power of O. Khomenko, not only doesn't give the clear answer about the initial undisturbed and broken stress strain state of the massif by workings, but has even not created a certain approach to its definition. About accounting of regularities of power exchange in the massif around developments with increasing in depth of mining, there is no conversation at all.

2. The analysed scientific theories about the rock pressure upon underground mine workings with usage classification sign "state of the investigated massif" have been divided into 3 main classes: forces, deformations and states of the massif. Theories of forces support groups of hypotheses of dome state, beams and plates (Table 1). Theories of deformations consist of groups of destruction hypotheses, a relaxation, plastic flow of the broken massif, and group of hypotheses of a state - the thermodynamic theory. Respectively, P. Schulz, A. Heim, J. Talobr, W. Ritter, F. Engesser, N. Fayol, G. Mantsel, V. Trompeter, O. Kommerell were engaged in development of theories of forces. Adherents of theories of deformations are A. Leon, M. Protod'yakonov, F. Levinson-Lesing and A. Zaytsev, A. Dinnik, Dzh. Spelding, R. Fenner, A. Labass, V. Slesarev, R. Morrison, K. Ruppeneyt, S. Avershin, R. Kvapil, N. Hast, A. Savost'yanov. V. Lavrinenko with the thermodynamic theory and $\mathrm{O}$. Khomenko with the power theory of zone capsulation of underground mine workings are referred to researchers of the massif state.

3. Lack of systemacity in research and domination of applied format of theories haven't allowed authors to establish the sizes, shape, quantity of zones and the areas of deformations that formed in them, and the main thing, to open physical essence of the phenomenon which leads to zone structuring of the massif around mine workings. Since 1972, this phenomenon has been called as zone disintegration of rocks around mine workings and is actively investigated around the world until today. Recognition of this phenomenon as one of the most difficult problems of mining science, not giving in to the decision based on modern representations of physics became result of this research. O. Khomenko has disclosed physical essence of the studied phenomenon as zone capsulation of mine working by the system of ring power zones and described the physical processes proceeding in the safety capsule of mine working with appliation of synergetic methodological research at a stage of the analysis of scientific problem. 
Table 1 Classification of theories about rock pressure

\begin{tabular}{|c|c|c|c|c|c|c|}
\hline \multirow{2}{*}{ Class } & \multirow[b]{2}{*}{ Group } & \multicolumn{3}{|c|}{ Research } & \multirow[b]{2}{*}{ Scientific result } & \multirow[b]{2}{*}{ Main shortcoming } \\
\hline & & Name of the author & Country & Year & & \\
\hline \multirow{10}{*}{ 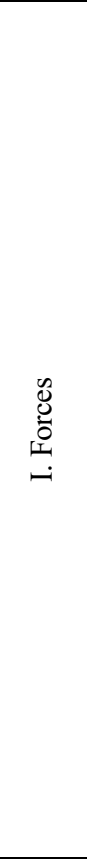 } & \multirow{7}{*}{$\stackrel{\mathscr{\Xi}}{\stackrel{0}{0}}$} & P. Schulz & Germany & 1867 & $\begin{array}{l}\text { Sizes and shape of the natural } \\
\text { balance dome }\end{array}$ & $\begin{array}{l}\text { Reliability of calculations up } \\
\text { to } 400 \mathrm{~m}\end{array}$ \\
\hline & & A. Heim & Switzerland & \multirow{2}{*}{1878} & $\begin{array}{l}\text { Equations of elastic deformations } \\
\text { balance }\end{array}$ & $\begin{array}{l}\text { There is no accounting of a side } \\
\text { thrust of rocks }\end{array}$ \\
\hline & & Dzh. Talobr & France & & $\begin{array}{l}\text { Picture of zones of unloading } \\
\text { concentration of stresses }\end{array}$ & $\begin{array}{l}\text { There is no calculation of zones } \\
\text { parameters }\end{array}$ \\
\hline & & W. Ritter & \multirow{3}{*}{ Germany } & 1879 & $\begin{array}{l}\text { Equations of pressure upon a } \\
\text { mine working's support }\end{array}$ & $\begin{array}{l}\text { There is no accounting of pressure } \\
\text { of the leaning rocks }\end{array}$ \\
\hline & & F. Engesser & & 1882 & $\begin{array}{l}\text { Equations of pressure upon } \\
\text { support for the granular medium }\end{array}$ & $\begin{array}{l}\text { Narrow scope of calculations } \\
\text { application }\end{array}$ \\
\hline & & W.Trompeter & & 1899 & $\begin{array}{l}\text { Model of zones of the lowered and } \\
\text { increased pressure }\end{array}$ & $\begin{array}{l}\text { There is no description of } \\
\text { physical processes }\end{array}$ \\
\hline & & O. Kommerell & Austria & 1912 & $\begin{array}{l}\text { Parameters of the stable } \\
\text { equilibrium dome }\end{array}$ & $\begin{array}{l}\text { Calculation is executed according } \\
\text { to the natural data }\end{array}$ \\
\hline & \multirow{3}{*}{$\begin{array}{l}\overbrace{\grave{m}}^{\infty} \\
\text { i } \\
i\end{array}$} & P. Schulz & Germany & 1867 & $\begin{array}{l}\text { Admissible length of exposure of } \\
\text { mine working's roof }\end{array}$ & Calculation for immediate roof \\
\hline & & H. Fayol & France & 1885 & $\begin{array}{l}\text { Model of stratification, bending, } \\
\text { scarification }\end{array}$ & \multirow{2}{*}{$\begin{array}{l}\text { There is no mathematical } \\
\text { apparatus }\end{array}$} \\
\hline & & G. Mantsel & Germany & 1894 & $\begin{array}{l}\text { Pressure model from the leaning } \\
\text { rock strata }\end{array}$ & \\
\hline \multirow{11}{*}{ 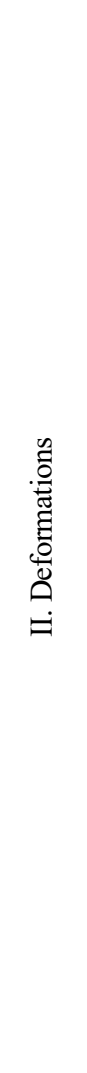 } & \multirow{11}{*}{ 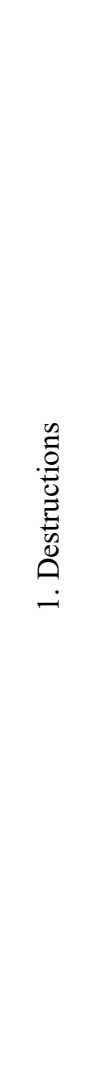 } & A. Leon & Austria & \multirow{2}{*}{1908} & $\begin{array}{l}\text { Model of calculation of stresses } \\
\text { in the rock massif }\end{array}$ & $\begin{array}{l}\text { Stresses on mine working's } \\
\text { contour }=0\end{array}$ \\
\hline & & M. Protod'yakonov & Ukraine & & $\begin{array}{l}\text { Model of rocks pressure upon } \\
\text { mine working's support }\end{array}$ & $\begin{array}{l}\text { Reliability of calculations up to } \\
200 \mathrm{~m}\end{array}$ \\
\hline & & $\begin{array}{l}\text { F. Levinson- } \\
\text { Lesing } \\
\text { A. Zaytsev }\end{array}$ & Russia & 1915 & $\begin{array}{l}\text { Dependences of stress level of the } \\
\text { massif ofrom mine working's } \\
\text { shape }\end{array}$ & $\begin{array}{l}\text { Stresses on mine working's } \\
\text { contour }=0\end{array}$ \\
\hline & & A. Dinnik & Ukraine & 1925 & $\begin{array}{l}\text { Calculation of stresses in the } \\
\text { undisturbed rock massif }\end{array}$ & $\begin{array}{l}\text { Loading upon support doesn't } \\
\text { calculated }\end{array}$ \\
\hline & & Dzh. Spelding & & 1937 & $\begin{array}{l}\text { Model of unloading of initial } \\
\text { stresses }\end{array}$ & $\begin{array}{l}\text { There is no mathematical } \\
\text { apparatus }\end{array}$ \\
\hline & & R. Fenner & Russia & 1938 & $\begin{array}{l}\text { Deformations in unloading } \\
\text { concentration zones }\end{array}$ & $\begin{array}{l}\text { There is no description of } \\
\text { physical processes }\end{array}$ \\
\hline & & V. Slesarev & & 1948 & $\begin{array}{l}\text { Model of steady equivalent case } \\
\text { bays }\end{array}$ & $\begin{array}{l}\text { Mine working's steadiness on its } \\
\text { length }\end{array}$ \\
\hline & & S. Avershin & Kirghizia & 1955 & $\begin{array}{l}\text { Model of action of abutment } \\
\text { pressure forces }\end{array}$ & $\begin{array}{l}\text { There is no mathematical } \\
\text { apparatus }\end{array}$ \\
\hline & & R. Kvapil & Russia & 1958 & $\begin{array}{l}\text { Model of zones of unloading } \\
\text { concentration of stresses }\end{array}$ & $\begin{array}{l}\text { There is no description of } \\
\text { physical processes }\end{array}$ \\
\hline & & N. Hast & England & 1967 & $\begin{array}{l}\text { Measurements of elastic } \\
\text { deformations in the rock massif }\end{array}$ & $\begin{array}{l}\text { There is no scientific } \\
\text { substantiation }\end{array}$ \\
\hline & & A. Savost'yanov & Ukraine & 1974 & $\begin{array}{l}\text { Theory of destruction of the } \\
\text { layered massif } \\
\text { and formation of abutment } \\
\text { pressure zones }\end{array}$ & $\begin{array}{l}\text { Empirical dependences } \\
\text { according to natural data of } \\
\text { research }\end{array}$ \\
\hline \multirow{2}{*}{ 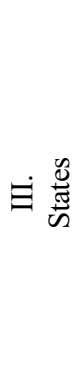 } & 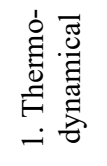 & V. Lavrinenko & \multirow{2}{*}{ Ukraine } & 1975 & $\begin{array}{l}\text { Theory of stresses formation in } \\
\text { the undisturbed and broken } \\
\text { massifs of rocks }\end{array}$ & $\begin{array}{l}\text { There is no scientific } \\
\text { description of processes in } \\
\text { zones of stresses concentration }\end{array}$ \\
\hline & 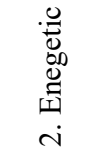 & O. Khomenko & & 2015 & $\begin{array}{l}\text { Theory of zone capsulation by the } \\
\text { massif of underground mine } \\
\text { workings }\end{array}$ & There is no patented software \\
\hline
\end{tabular}




\section{References}

[1] Khomenko, O., \& Kononenko, M. (2017). Phenomenon of underground working encapsulation: identification, modeling \& appliance. Collection of research papers of NMU. (52), 166-177.

[2] Kaydo, I. (2009). O prirode yavleniya zonalnoy dezintegratsii gornyih porod vokrug podzemnyih vyirabotok (gipoteza). GIAB, (1), 16-21.

[3] Khomenko, O., Kononenko, M., \& Netecha, M. (2016). Industrial research into massif zonal fragmentation around mine workings. Mining of Mineral Deposits, 10(1), 50-56.

[4] Kononenko, M., Khomenko, O., Sudakov, A., Drobot, S., \& Lkhagva, Ts. (2016). Numerical modelling of massif zonal structuring around underground working. Mining of Mineral Deposits, 10(3), 101-106.

[5] Khomenko, O.Ye. (2016). Geoenergetics of underground mining of ore deposits. Dnipro.: NMU.

[6] Heim, A. (1878). Mechanismus der Gebirgsbildung im Anschluss an die geologische Monographie der Toedi-Windgaellen-Gruppe. Bäle.

[7] Trompeter, W.H. (1899). Die Expansivkraft im Gesteine als Hauptursache der Bewegung den Bergbau umgebenden Gebirges. Essen. Druck und Verl. fon G.D. Baedeker.

[8] Schulz, P. (1867). Untersuchungen über Dimensionen der Sicherheitsfehlern für den Saarbrücker Stein-Kohlenbergbau. Zeitschr. f. das Berghütten- und Salinirenwizen im Preuss Staate.

[9] Ritter, W. (1879). Die Statik der Tunnelgewölbe. Berlin.: J. Springer.

[10] Engesser, F. (1882). Über Erddruck gegen innere Stützwände (Tunnelwande). Deutsche Bauzeitung.

[11] Fayol, H. (1885). Nate sur les mouvements de terrain provoques par l'exploitation des mines, Bull. de la soc. de l'industrie Min., 805.

[12] Kommerell, O. (1912). Statische Berechnung von Tunnelmauerwerk, Berlin.

[13] Leon, A. (1908). Ueber die Störungen der Spannungsverteilung, die in elastichen Körpern durch Bohrungen und Bläschen entstehen. Öesterr. Wochen-Schrift für den Öffentlichen Baudienst, Heft 9, 163.

[14] Levinson-Lesing, F., \& Zaytsev, A. (1915). K voprosu o davlenii v tunelyakh. Petrograd.

[15] Protod'yakonov, M.M. (1933). Davlenie gornykh porod i rudnichnoe kreplenie, Ch. 1, Davlenie gornykh porod. Moskva-Leningrad-Novosibirsk.: GNTI.

[16] Dinnik, A.N. (1925). O davlenii gornykh porod i raschet krepi krugloy shakhty. Inzh. Rabotnik (7), 1-12.

[17] Tsimbarevich, P.M. (1934). Mekhanika gornykh porod. Moskva-Leningrad.: ONTI.

[18] Slesarev, V.D. (1948). Mekhanika gornykh porod. Moskva.: Ugletekhizdat.

[19] Spelding, Dzh. (1961). Upravlenie gornym davleniem. Teoriya i praktika. Gornoe davlenie, 242-274.

[20] Fenner, R. (1961). Issledovaniya gornogo davleniya. Gornoe davlenie, 5-68.

[21] Labass, A. (1961). Davlenie gornykh porod v ugol'nykh takhtakh. Gornoe davlenie, 59-164.

[22] Ruppeneyt, K.V., \& Liberman, Yu.M. (1960). Vvedenie v mekhaniku gornykh porod, Moskva.: Gosgortekhizdat.

[23] Liberman, Yu.M. (1969). Davlenie na krep' kapital'nykh vyrabotok, Moskva.: Nauka.

[24] Avershin, S.G. (1955). Gornye udary. Moskva.: Ugletekhizdat. 
[25] Kvapil, R. (1958). Zur Theurie der Gtsteinszenstörung, Jntern. Gebirgsddrucktagung, Zeipzig, Akademieverlag, Berlin.

[26] Morrison, R.G. (1948). Theoy and the Practical Problem of Rock Burst, End. and Min. Journ. 23(149).

[27] Kvapil, R. (1961). Novye vzglyady na voprosy teorii davleniya gornykh porod $i$ gornykh udarov. Gornoe davlenie, 275-297.

[28] Hast, N. (1958). The measuriment of rock pressure in mines, Sveriges Geologiska Undersöking. Ser. C. 560 Arsbok, 52(3), 183.

[29] Gzovskiy, M.V., Turchaninov, I.A., Markov G.A. i dr. (1973). Napryazhennoe sostoyanie zemnoy kory po dannym izmereniy $v$ gornykh vyrabotkakh $i$ tektonofizicheskogo analiza. Napryazhennoe sostoyanie zemnoy kory: nauch.- tekhn. sb., 32-49.

[30] Oberst, L. (1962). In situ dermination of stress in rock. Min. Engng, (148), 51-58.

[31] Savost'yanov, A.V., \& Klochkov, V.G. (1992). Upravlenie sostoyaniem massiva gornykh porod. Kiev.: NMK VO.

[32] Lavrinenko, V.F. (1986). Preobrazovanie energii i formirovanie poley napryazheniy v massive vokrug vyrabotki. Izv. vuzov. Gornyy zhurnal, (4), 5-11.

[33] Khomenko, O.Ye. (2012). Implementation of energy method in study of zonal disintegration of rocks. Naukovyi Visnyk Natsionalnoho Hirnychoho Universytetu, (4), 44-54.

[34] Khomenko, O.Ye., Sudakov, A.K., Malanchuk, Z.R., \& Malanchuk, Ye.Z. (2017). Principles of rock pressure energy usage during underground mining of deposits. Scientific bulletin of National Mining University, (2), 35-43.

[35] O. Khomenko, M. Kononenko, D. Astafiev, Effectiveness of Geo-Energy Usage during Underground Mining of Deposits, Advanced Engineering Forum. 22 (2017) 100-106.

[36] Khomenko, O., Kononenko, M., \& Danylchenko, M. (2016). Modeling of bearing massif condition during chamber mining of ore deposits. Mining of Mineral Deposits, 10(2), 40-47.

[37] Kononenko, M., \& Khomenko, O. (2010). Technology of support of workings near to extraction chambers. New Techniques and Technologies in Mining, 193-197.

[38] Khomenko, O.Ye., \& Maltsev, D.V. (2013). Laboratory research of influence of face area dimensions on the state of uranium ore layers being broken. Naukovyi Visnyk Natsionalnoho Hirnychoho Universytetu, (2), 31-37.

[39] Zhanchiv, B., Rudakov, D.V., Khomenko, O.Ye., \& Tsendzhav, L. (2013). Substantiation of mining parameters of Mongolia uranium deposits. Naukovyi Visnyk Natsionalnoho Hirnychoho Universytetu, (4), 10-18. 